Reference Services Review, v. 17, issue 2, 1989, p. 27-39.

ISSN: 0090-7324

DOI: $10.1108 / \mathrm{eb} 049054$

http://www.emeraldinsight.com/journals.htm?issn=0090-7324

(C) 1989 MCB UP Ltd

\title{
Current Readings on the Iran-Iraq Conflict and Its Effects on U.S. Foreign Relations and Policy
}

\section{Magda El-Sherbini}

The conflict between Iran and Iraq is not new; it dates from long before September 1980. In fact, the origins of the current war can be traced to the battle of Qadisiyah in Southern Iraq in 637 A.D., a battle in which the Arab armies of General Sa'd ibn Abi Waqqas decisively defeated the Persian army. In victory, the Arab armies extended Islam east of the Zagros Mountains to Iran. In defeat, the Persian Empire began a steady decline that lasted until the sixteenth century. However, since the beginning of that century, Persia has occupied Iraq three times: 1508-1514, 1529-1543, and 1623-1638. Boundary disputes, specifically over the Shatt al-Arab Waterway, and old enmities caused the wars. In 1735, belligerent Iranian naval forces entered the Shatt al-Arab but subsequently withdrew. Twenty years later, Iranians occupied the city of Sulimaniah and threatened to occupy the neighboring countries of Bahrain and Kuwait. In 1847, Iran dominated the eastern bank of the Shatt al-Arab and occupied Mohamarah in Iraq.

The Ottoman rulers of Iraq concluded a number of treaties with Iran, including: the treaty of Amassin (1534-55); treaties signed in 1519, 1613, and 1618; and the treaty of Zuhab, signed in 1639. Yet another treaty, the treaty of Erzerum in 1823, failed once again to resolve the dispute. In 1847, Britain and Russia attempted to intervene in the Persian-Ottoman war over the Shatt al-Arab Waterway and imposed the second treaty of Erzerum. Under that treaty, the cities of Abadan, Khorramshahr, and the eastern bank of the Shatt became a part of Persia. None of these treaties, however, resolved the border problem.

The current Iraqi government, led by Saddam Hussein, hoped the fall of the Shah of Iran in 1979 and the establishment of the Islamic republic would lead not only to a resolution of the border problem in Iraq's favor but also to improved relations between the two nations. Contrary to expectations, however, relations worsened and acquired dangerous sectarian religious overtones. These new hostilities led in September 1980 to the latest war between the two nations.

Although the Iran-Iraq war has been limited primarily to those two countries, it has the potential of spreading at any time to the rest of the Arabian/Persian gulf. Moreover, it has increased international tensions throughout the world. Specifically, the United States has had troubled relations with both countries, but especially Iran. The overthrow of the Shah in January 1979 ended an intimate Iranian-American relationship of over twenty-five years. The mutual hostility and tension between the American and Khomeini governments was intensified by the seizure on 4 November 1979 of the American embassy in Tehran, during which a number of American hostages were taken. The United States retaliated by freezing all Iranian government property and interests in the United States and by prohibiting the purchase of Iranian oil and the shipment of weapons to Iran. Although the outbreak of the Iran-Iraq war influenced the eventual release of the hostages after 444 days, relations between Iran and the United States have remained tense. 
The Iran-Iraq conflict has been the subject of numerous publications. This essay suggests a condensed reading list that will enable the interested reader to develop a general background of the conflict as well as its economic, political, and religious implications, its impact on the Gulf region, and its impact on the United States and United States foreign policy. This bibliographic essay includes most of the books, periodicals, bibliographies, and databases on the topic dating from 1980 to 1988 in both English and Arabic. The literature has been classified under seven broad categories: the root of the Iranian-Iraqi conflict; Iran-United States relations; the American hostages; the Iran-Contra Affair; periodicals and index resources; databases; and bibliographies.

\section{THE ROOTS OF THE CONFLICT}

As with all wars, the Iran-Iraq conflict has general causes as well as specific ones. The general causes can be traced to the cultural divisions that have separated the Arabs and Persians since the battle of Qadisiyah in 637 A.D. Another major cause is the split of Islam into the Shi'ite and Sunni sects. Perhaps the most specific reason for the conflict is the centuries-old quarrel over the Shatt al-Arab Waterway. Another specific cause is Iran's attempts to export its Islamic revolution to the Shi'as of other Persian Gulf states.

Since the current crisis began in 1980, many publications have offered different perspectives of the war, its origins, and its implications. Shakir Sabir Dabit, in Tarikh al-Munaza'at Wa-al-Hurud Bayna al-Iraq Wa-Iran (1984), provides a significant overview of the origins of the conflict. This Arabic language text, volume one of a two-volume set, gives a chronological account of the roots of the conflict, dating from 3200 B.C. until the Ottoman-Safavid Empire dispute over Iraq in 1534. Dabit discusses the history of the two countries, the war between them before and after the fall of Babylon, the crisis that occurred when the Arab Muslims opened Faris, the battle of Qadisiyah, and the assassination of the Khalifah 'Umar ibn al-Khat-tab. Dabit also examines the series of wars between Arab and Persian forces before and after the Abbasid period. The book is extensive, well written, and thoroughly documented. It includes a comprehensive bibliography and maps. A valuable resource for university libraries, this book is most appropriate for historians and readers with Arabic language skills.

Iran-Iraq: Roots of Conflict (1982), by Tareq Y. Ismael, professor of political science at the University of Calgary, Canada, is an impressive collection of documents that explains the legal, historical, and ideological dimensions of the Iran-Iraq war. Ismael analyzes the ideological bases of the regimes of Saddam Husayn and the Ayatollah Khomeini.

Another useful account, Iraq-Iran Conflict: Questions and Discussions (1981), by Tareq Aziz, answers a number of questions that have been raised by various Arab political parties: who started the war; what was behind the war; why has the war been prolonged; and how long will it continue? The book also deals with the Iran-Iraq war in relation to the Arab-Israeli conflict and with Iran's dealings with Israel during both the rule of the Shah and Khomeini. The author answers these questions from an Iraqi perspective.

Iraq and Iran: The Years of Crisis (1984), by Jasim M. Abdulghani, examines Iraq's relationship with Iran since the Ba'th political party's accession to power in Iraq in 1968. This book includes discussions of the historical and legal aspects of the Shatt al-Arab boundary dispute and the impact of the Shah's downfall and Khomeini's rise to power in Iran on Iraq and the Gulf region. Abdulghani provides a clear explanation of the complicated factors that ultimately led to the outbreak of the war. In spite of his focus on Iraq, he is reasonably objective in showing the depth of the hostility between the two countries and the reasons for the conflict. 
Husayn Sulayman al-Ajrab's Judhur Harb al-Khalij (1986) is another Arab language historical account of the Iran-Iraq war. It is the first volume of a projected two-volume set. Ajrab concludes that the roots of the conflict predate the Christian era and that Iran's objective is to destroy Iraqi civilization. It is useful as an expression of the Iraqi point of view. Sreedhar, in Iraq-Iran War, presents a series of articles covering all aspects of the war. His purpose is to provide readers with a clear understanding and assessment of the war. al-Sira' al-'Arabi al-Farisi (1981) is published in Arabic, English, and French. This historical account of the old and new conflict is divided into three parts: the first section explains the direct causes of the 1980 war; the second section explains the historical roots of the problem; and the third section discusses the recent conflict. Appendixes include official documents and treaties of the boundary dispute and maps of the Shatt al-Arab, Arabistam, Arab countries, and the Iran-Iraq boundaries. The work also contains a bibliography and index.

Sabah Salman, in Adwa' 'ala al-Harb al-'Iraqiyah al-Iraniyah (1981), presents his analysis of the war, focusing on the 1980 outbreak. He criticizes the Iranian government and the Khomeini regime. In Kalam Hadi fi Jaw Multahib (1980), Nasif Awwad traces the relationship between Iran and Iraq from 1968 to 1980. He considers the question of whether Khomeini will succeed in his regime where the Shah failed and criticizes Syria and Libya's attitude toward the war. Hamid Sa'id wrote al-Dars al-Iraqi fi Harb Radd al-'Udwan (1982) and Qira'ah fi Awraq 'Arabiyah (1983). These two books reflect the Iraqi point of view and criticize the Khomeini regime.

The Iran-Iraq War has brought death and suffering to hundreds of thousands of people on both sides. It has affected the economies of both countries and has increased international tension. Addressing the political issues, Ralph King, research associate at the International Institute for Strategic Studies in London, wrote The Iran-Iraq War: The Political Implications (1987). This study addresses the political complexities of the war between the two countries and examines its broader ramifications. King considers the origins of the war and the political and economic effects it has had on Iran and Iraq. He also provides an excellent analysis of the reactions of the other regional states, both Arab and non-Arab, and an examination of international response, specifically from the superpowers. Comprehensive notes and appendixes add to the value of the text. King's study is recommended for academic libraries as well as for general readership.

Mark Heller's The Iran-Iraq War: Implications for the Third Parties is the best single assessment of the local, regional, and international ramifications of the Iran-Iraq war. Heller does not focus on the origins of the conflict nor on the causes of the fighting, but rather on the political and security interests of the various factions in the Middle East and elsewhere. The author discusses: the Arab states in the Persian Gulf that are most immediately affected by the war; the extent to which other Arab States, such as Jordan and Syria, have become involved; the roles of the major international powers, including France; and the future effect of the war in the gulf.

The Iran-Iraq War: An Historical, Economic, and Political Analysis (1982), edited by M. S. El-Azhary, contains nine articles discussing various dimensions of the war. Most of these essays were presented at the Shatt al-Arab Symposium at the University of Exeter, England, in July 1982. The best selection, the editor's "The Attitudes of the Superpowers towards the Gulf War," emphasizes the lack of influence of either Moscow or Washington upon the combatants. El-Azhary asserts that the war will not spread to neighboring countries nor will it adversely affect the flow of oil out of the Persian Gulf. This book aims to increase the reader's understanding of the Iran-Iraq War and its effect on international politics. Although the book focuses on Iraq, general readers are likely to find it useful.

Iran-Iraq War: Old Conflict, New Weapons (1983) is a collection of essays on the origins 
of the conflict and its impact on the region. The articles are edited by Shirin Tahir-Kheli and Shaheen Ayubi. The subject matter varies; three articles discuss the military, economic, and political consequences of the conflict. In general, the selections discuss various aspects of the war itself, the internal politics of Iran and Iraq, and the interaction of regional and global factors surrounding the war. Overall, this collection of essays is valuable for illuminating the tragic nature of the war.

A seminar sponsored by the Center of International Studies at the Woodrow Wilson School of Public and International Affairs, Princeton University, resulted in the publication of The Iraq-Iran War: Issues of Conflict and Prospects for Settlement (1981), edited by Ali E. Hillal Dessouki. Contributors to this volume offer an overview of the war, perceptions of the adversaries, global and regional implications, and prospects for settlement. Each chapter provides a very useful discussion. Appendixes include an explanation of the Algiers Declaration of 6 March 1975, the joint communique between the two peoples, and the treaty concerning the state frontier and neighborly relations between the two countries. A selected bibliography and a chronology of the war add value to the book.

The economic impact of the war on the Middle East and on the international market is discussed in The Iran-Iraq War: Its Economic Implications, by Eliyahu Kanovsky (1983). This useful work offers the reader a quick analysis of the economic impact of the war on the combatant countries, on other Middle Eastern countries, and on international oil markets in general. The notes and appendixes are valuable.

Khalid Izzi has written two historical and legal studies of the Shatt al-Arab dispute. In The Shatt al-Arab Dispute: A Legal Study (1981), Izzi thoughtfully discusses the origins of the dispute, taking into consideration the historical background of the conflict as a whole. Readers should keep in mind that the author is a former director-general of the Political Department of the Iraqi Council of Ministers, so his point of view is Iraqi. However, the book provides a good general analysis of the war. Izzi's other book, al-Niza'al-'Iraqi al-Irani fi al-Qanun al-Dawli (1983) is an Arabic language legal study of all aspects of the war. It includes appendixes containing letters, official documents and treaties, and comprehensive notes.

Two books examine the press coverage the war has received. Wijhat Nazar al-Sihafah al-Gharbiyah fi al-Niza' al-Iraqi al-Irani (1983) expresses the foreign press' viewpoint of the war; and Sada al-Harb (1983) is a selection of pieces from the world press about the war. The latter book was published in Iran, and most of the excerpts are antagonistic toward Saddam Hussein's regime.

There are two accounts of the effort toward peace in the Persian Gulf region. Juhud al-Salam al-Dawliyah li-Iqaf al-Harb al-Iraqiyah al-Iraniyah (1983) examines international efforts to stop the Iranian-Iraqi war from the Iraqi point of view. However, in al Harb al-Iraqiyah al-Mafrudah 'ala Jumhuriyat Iran al-Islamiyah (1983), Iran accuses Iraq of rejecting peaceful ways to solve the boundary problems. The appendixes in this book include documentation of the breaking of the 1975 treaty between the two countries.

Five additional books about the war, written in Arabic, are very useful for Arabic readers. Mulahazat Hawla Qadiyat al-Harb ma'a Iran, by Sa'dum Hammadi (1982), is a group of essays initially published in Al-Watan al-'Arabi Journal (Paris) and al-Thawrah newspaper (Baghdad). Naz-rah ila 'Amayn min al-Harb is an account of the Iraqi attack on Iran two years after the outbreak of the war. al-Ma'rakah wa-Muqaddimat al-Nasr (1982), by Sabah Yasin, is intended to inflame the Iraqi people and encourage them toward victory. 'Udwan al-Nizam al-Iraqi Jarimah ma'a Sabq al-Israr (1984), written by Karra Haydar, discusses Iraqi preparations for the war. It 
also includes a chronological index of Iraqi hostilities toward Iran. al-Iman Yuqawimu al-I'tida' (1982), in Arabic and English, features photographs depicting a pictorial history of the conflict. It shows both how the war has imposed on the Iranian people and how they have resisted it.

Other Arabic books related to the subject and very useful for general Arabic language readers are Fi Qissat al-Harb (1984), by 'Ali 'Abd al-Husayn Mukhif; Munaqashah fi al Niza' al-Iraqi al-Irani (1984), by Hasan Muhammad Tawalibah; al-Munaza 'at al-Dawliyah (1986), by Suhayl Husayn Fatlawi; Mala-him Khalidah fi Qadisiyah Saddam (1984), by Hani Wuhayyib; Khumayni al-Tajribah al-Mayyitah (1984), by Muhammad 'Abd al-Muttalib Bakka; and Qadisiyat Saddam (1984), by 'Abd al-Mun'im Ghaz-zali.

\section{UNITED STATES-IRAN RELATIONS}

The history of relations between the United States and Iran can be traced from 1856, when a treaty of Friendship and Commerce was signed, through April 1980, when the abortive attempt to rescue the American hostages in Tehran was made. Since that event, many books have been published concerning these relations.

The United States and Iran: A Documentary History (1980), edited by Yonah Alexander and Allan Nanes, traces this history with help from government documents. This book presents a fascinating account for general readers interested in history.

Another historical account can be found in Paved with Good Intentions: The American Experience and Iran (1980), by Barry Rubin. The author of this book traces the history of the two countries' relations from 1829, when the first American missionaries arrived in Persia, through the rescue attempt in April 1980. Rubin provides a fine analysis of the Islamic revolution, and, in the closing chapter, he gives the reasons for the Shah's fall from power. There is also an excellent appendix on the role of the American media vis-a-vis Iran, as well as a useful chronology of events in Iran from January 1973 through June 1980.

Taken together, two books provide a good analysis of the history of the American involvement in Iran: The Origins of the Iranian-American Alliance, 1941-1953 (1987), by Mark Hamilton Lytle; and Involvement by Invitation: American Strategies of Containment in Iran (1987), by Kuross A. Samii. Lytle is a historian; Samii is a political scientist. Both works treat the relations of the U.S. with Iran, and both deal largely with the 1940s. Lytle concentrates on the period from 1941 to 1947; whereas Samii considers the pre-1941 period of U.S.-Iranian relations to be important for understanding subsequent problems. Lytle identifies four key factors that shaped "the State Department's commitment to an Iranian alliance," including bureaucratic rivalries, security concerns, a profound mistrust of the Soviet Union and hatred of communism, and a sense of American exceptionalism. Samii, in his work, describes two distinct historical periods of American involvement in Iran. The first begins in 1911 with Morgan Shuster's mission as the financial adviser to the Iranian government and ends in 1954 with the imposition upon Iran of an Anglo-American oil agreement. The second period covers the U.S. government's involvement since 1954, leading to the hostage situation that erupted in 1980. Samii criticizes American policymakers, with the exception of John F. Kennedy, for failing to realize that "America's interests are threatened as much by the internal blemishes of the third world as they are by the communist penetration of these countries." Both books are accessible to and informative for general readers.

The relationship between Iran and the U.S. before and after the fall of the Shah and during the hostage crisis is explored in Debacle: The American Failure in Iran (1981), by Michael 
Ledeen and William Lewis. The authors argue that the Carter administration did not understand the Iranian revolution. They emphasize two points: the vital importance of American's role during the Iranian revolution and Washington's inability to cope with this issue. The authors provide a useful analysis of the foreign policy debacle in Iran for readers with an interest in politics.

John D. Stempel served as political officer, deputy chief, and finally acting chief of the U.S. Political Section in the American Embassy in Tehran from July 1975 until June 1979. He wrote Inside the Iranian Revolution (1981) to attempt to explain the strengths and weakness of the Shah's regime. The final three chapters investigate the options that were available to Iran and the United States before and during the revolution, and the wider meaning of the revolution itself. The book is informative and readable.

Hafeez Malik's Soviet-American Relations with Pakistan, Iran, and Afghanistan (1987) is a collection of conference papers dealing primarily with the complex relations between the United States, the U.S.S.R., Pakistan, Iran, and Afghanistan and the effect of the foreign policies of the three southwest Asian states toward India and Iraq. Despite the fact that there is some overlap in the collection, the essays are highly informative. The text contains an index and notes.

Two books consist of exposes of the Reagan administration's extensive covert activities in Iran. Reagan's Secret Wars (1984), by Jay Peterzell, examines the secret foreign policy of the Reagan administration. Using interviews, press reports, and government documents, Peterzell details the secret campaigns conducted against Nicaragua, Afghanistan, Cambodia, Libya, and Iran. He suggests that covert action is used by the White House to pursue vague, destructive goals. This is a useful compendium of covert actions for the first two years of the Reagan administration. Each chapter is accompanied by helpful footnotes. The Iran-Contra Connection (1987), by Jonathan Marshall, Peter Dale Scott, and Jane Hunter, is another critique of U.S. involvement in foreign affairs. Notwithstanding the title's implication that this book is concerned with the Iran-Contra affair, the book is actually a broad attack leveled at the Reagan administration's methods. It deals little with Iran, the Nicaraguan Contras, or the United States' relations with either.

From June of 1977 to April 1979, William Sullivan served as U.S. ambassador to Iran. He survived the first assault on the U.S. Embassy compound on 14 February 1979. Mission to Iran (1981) recounts his personal experiences during the period immediately preceding the hostage crisis. The book is fascinating reading because Sullivan underscores the readiness of the opposition to maintain good relations with the United States after the overthrow of the Shah.

\section{AMERICAN HOSTAGE CRISIS}

The hostage crisis occupied the attention of the U.S. government for more than fourteen months. It was a nightmare for all of America. A matter of confounding complexity, the hostage crisis involved myriad financial, legal, political, and practical details and decisions. Relations between the United States and Iran deteriorated quickly after the Shah withdrew from Iran, and one result was that the newly appointed U.S. ambassador, Walter L. Culter, was rejected by the new revolutionary government.

During the Iranian revolution in 1978 and 1979, forty-five thousand Americans who had been living and working in Iran were evacuated. The size of the embassy staff was cut from four hundred to only sixty-five. Then, the 14 February 1989 attack on the American Embassy pushed the State Department to move quickly to again improve security for those Americans who remained in Iran. At this time, the quality of the Iranian guard force protecting the embassy was 
improved.

The admission of the exiled Shah of Iran, Muhammad Reza Pahlavi, to the United States for treatment of cancer on 22 October 1979 generated increasingly hostile daily protests outside the American Embassy compound. On 4 November, four hundred and fifty angry demonstrators appeared outside the embassy and took up the chant, "Death to the Shah! Death to Carter! Death to America!" The reason given for the ensuing takeover of the American Embassy in Tehran, then, was the admission of the Shah to the United States. Religious groups in Iran claimed that the United States would try to subvert the revolution from its course and allow the Iranian secular leadership to rebuild a relationship with the U.S.

Among the great volumes of literature on the hostage crisis, several studies stand out. Sidney Moody, in 444 Days: The American Hostage Story (1981), compiles a great deal of information and presents the story of the hostages through the days of hope and despair in Tehran, Washington, and elsewhere in the world. Among the book's most valuable features are the illustrations accompanying the text and the brief information about the hostages that accompanies the photographs. Although the book is very well-documented and valuable for general readers, it lacks bibliographical sources.

Christos P. Ioannides' America's Iran: Injury and Catharsis (1984) examines the causes of the rupture between the United States and Iran and the historical forces that caused it. The first part of the book deals with America's relations with Iran before the fall of the Shah and the effect of the revolution in 1979 on United States policy toward Iran. In the second part, Ioannides discusses the causes of the hostage crisis. His concluding chapter focuses on the impact of the hostage crisis on the 1980 presidential election and on the long-term effects of the crisis on American policy. The bibliography of primary and secondary sources is excellent, as are the extensive notes and index. It is a good acquisition for all libraries.

A journalistic account of the behind-the-scenes diplomatic negotiations to free the hostages can be found in Pierre Salinger's America Held Hostage: The Secret Negotiations (1981). The title of the book bears the same name as the television documentary that Salinger produced for ABC News, for whom he is the Paris correspondent. Salinger provides an extremely interesting account of the frustrating process that eventually led to freedom for the American hostages. His background material on Iranian policies illuminates the events surrounding the crisis. He also criticizes American policy in Iran. America Held Hostage is exciting narrative reading for both specialists and general readers.

In Crisis: The Last Year of the Carter Presidency (1982), Hamilton Jordan, the former White House chief of staff under the Carter administration, presents a selective history, concentrating on the continuing hostage crisis and the difficult re-election campaign. The author reveals the inner workings and tensions of the administration, dating from the seizure of the U.S. embassy in Tehran to President Carter's meeting with the released hostages in Germany. Although his account is highly personal, Jordan also makes use of interviews with eighty-three key people and of official documents and memoranda and his secretary's diary. Carter's (and Jordan's) weaknesses are discussed. Crisis will satisfy the curiosity of both general readers and political scientists.

American Hostages in Iran: The Conduct of a Crisis (1985), edited by Warren Christopher, deputy secretary of state during the Reagan administration, examines the crisis through the eyes of U.S. policymakers. It traces the role of senior advisers to the president, such as the secretary of state, the secretary of the treasury, and the president's national security adviser. American Hostages analyzes the human, political, military, and economic choices that had to be confronted. 
The contributors reveal the wide range of factors involved in the crisis by describing the interactions of the policymakers with the families of the hostages, private individuals who wished to get involved, international bankers whose interests were dramatically affected, the media, and the public. The most detailed information is given in chapters one, two, and seven by Harold Saunders, former secretary of state for Near Eastern and South Asian affairs. Saunders discusses the situation in Iran from the crisis in 1979 and the U.S. response through the collapse of negotiations for release of the hostages in early 1980. In one conclusion, Senator Abraham Ribicoff offers his observations and thoughts about the lessons this experience suggests for the future. It is an extremely detailed volume recommended to general readers, academic libraries, and community colleges.

Paul Ryan, a Research Fellow at the Hoover Institute, has authored the well-written and thoroughly documented The Iranian Rescue Mission: Why it Failed (1985). In it, Ryan argues that the Iranian episode was plagued from the beginning with military and political shortcomings and blunders. His analysis of the rescue attempt is calmly reasoned. Ryan has included a good glossary and bibliography. The work is appropriate for general readers as well as graduates studying military strategy.

Finally, after the ordeal of the American hostages was over, it was commonly reported that the hostages felt that much of what had been written about them in the popular press was neither accurate nor truthful. The hostages believed that most of the information received by the American public about their experiences was based on speculation, rumor, and the Iranian militants' own propaganda. The 444 Days: The Hostages Remember (1985) is a personal narrative written by Tim Wells. This oral history is an attempt to redress that inaccuracy. Wells tries to describe the actual circumstances of the hostages' captivity. He interviewed the hostages and describes their experiences, incorporating their transcribed interviews into a dramatic narrative framework.

\section{IRAN-CONTRA AFFAIR}

The Iran-Contra arms scandal has garnered banner headlines since the news broke, in November 1986, that in August 1985 the United States had participated in secret dealings with Iran involving the shipment of advanced weapons, unobtainable on the international arms market, for cash and the freedom of American hostages in Lebanon. Israel was also involved in selling weapons to Iran for which the United States resupplied Israel.

The Contra Affair, as it has come to be known, raised serious questions about U.S. foreign policy and the rule of law in a democracy. The disclosures became the focus of substantial public attention. The public wanted to know who was responsible, what actions had been taken by the National Security Council (NSC) staff, how the decision was made to transfer arms to Iran, and why the Congress was never informed. President Reagan repeatedly disclaimed knowledge of the plan.

To shed light on the situation, he asked Congress to establish a special review board to examine the role of the NSC staff in these operations, including the arms transfers to Iran. The result of the inquiry was the Report of the President's Special Review Board (1987), popularly called, and published as, the Tower Commission Report. This report studies the NSC and its operations and staff since its creation forty years earlier. The board focused on the Iran-Contra issues and compiled the report from information and documentation provided by U.S. government departments and agencies and from interviews of current and former officials familiar with the events. The board divided the work into three major inquiries: the circumstances surrounding the 
Iran-Contra matter; other pertinent case studies that might reveal strengths and weaknesses in the operation of the NSC system under stress; and the service the NSC system provided eight different presidents since it began its operation in 1947. In the study, the board discloses that what happened was not new; every administration had faced similar issues, although the contexts differed. The report also includes specific mistakes of the NSC. It is a very useful reference for the public and government officials seeking to know the facts of the Contra Affair.

Since the Tower Commission Report is very detailed, the Index to the Tower Commission Report (1987), by James Sanchez, makes accessible precise information contained in the report. The Index uses many "see" and "see also" references. Variant spellings, nicknames, and the aliases of the people involved are cross-referenced. All individuals associated with a given agency or government are listed in "see also" cross-references under the name of that agency or country. A glossary of acronyms is integrated into the index. The name of each individual is followed by a parenthetical note indicating citizenship, titles, and position.

The Tower Commission Report is not the first report to investigate the Iran-Contra issue, nor will it be the last. On 6 January 1987, the Senate, by Senate Resolution 23, established the Select Committee on Secret Military Assistance to Iran and Nicaraguan Opposition. The next day, the House, by House Resolution 12, established the Select Committee to Investigate Covert Arms Transactions with Iran. The two chambers charged their respective committees with investigating four major areas: arms sales to Iran, possible diversion of funds to aid the Contras, violations of federal law, and involvement of the NSC staff in the conduct of foreign policy. When the investigations were complete, the two committees merged their findings and hearings, sharing all the information they obtained. They then combined their findings in a joint report titled Report of the Congressional Committees Investigating the Iran Contra Affair. The committees presented a comprehensive account concluding that the full story of the Iran-Contra Affair is complicated because of the inconsistent testimony and the failure of several witnesses to recall key matters and events. Objective evidence that could have resolved the inconsistencies and overcome the failures of memory was denied to the committees and, consequently, to history.

Preliminary Inquiry into the Sale of Arms to Iran and Possible Diversion of Funds to Nicaraguan Resistance (1987) is a report of the Select Committee on Intelligence of the United States Senate. This report is not an investigation. Its sole purpose was to gather in one place as many relevant documents as possible. The information was compiled from testimonies and documentation. Part I summarizes in narrative form the information given to the committee during the course of its inquiry. Part II sets forth certain unresolved questions and issues that the committee recommends be pursued.

The Iran-Contra Affair is rooted in the downfall, in the late 1970s, of two of the world's most enduring dictators: the Shah of Iran and President Anastasio Somoza of Nicaragua. Lieutenant Colonel Oliver L. North did not enter the stage until 1986, but shortly after, he became a key player in the affair. North has attracted considerable popular support. The immense amount of media coverage, including articles and photographs devoted to North, reflects the widespread interest in his life.

Peter Meyer's Defiant Patriot (1987) is a biography of North. Meyer traces the colonel's life from his birth in San Antonio, Texas, and his childhood in a small town in upstate New York, through his training at Annapolis and action as a Marine hero in Vietnam. Meyer discusses North's involvement in the invasion of Grenada, the bombing of Libya, the capture of the Achille Lauro hijackers, and his exploits involving Iran and Nicaragua. The title of Meyer's book reflects the unresolved question of whether Colonel North is a brilliant patriot or an articulate con man. It is a 
revealing account for general readers. Two appendices include the presentation of the Bronze and Silver Star medals to North by President Reagan and a chronology of North's life.

Another biographical account of North, The Story of Lieutenant Colonel Oliver North (1987), also describes his origins and his military valor in Vietnam. This book contains copies of some of the controversial documents that sparked so many heated exchanges during his testimony and reveals the day by day highlights of his appearances on Capitol Hill. It is a fascinating study, especially since the text is accompanied by photographs of the North family. Another book, The Octopus Eagle (1987), written by Michael Fredericks, tells how North got involved in the Iran-Contra scandal.

The Congressional Quarterly published the Iran-Contra Puzzle (1987) to help readers understand the affair. It provides an overview of the roots of U.S. policies toward Iran and the Contras, and of the revelation of the scandal and the investigations. This study examines in detail how the affair came to light, what the reaction was, and what actually happened. Separate chapters discuss the multiple investigations the affair triggered, those by the Senate Intelligence Committee, the Tower Commission, the House and Senate Iran-Contra Committees, and the Independent Council. The Iran-Contra Puzzle contains: a detailed chronology from 1979 through the testimony of 1987; brief profiles identifying the participants; excerpts from key testimonies of witnesses; and selected documents, speeches, press conferences, and statements that figured in the affair. It is a comprehensive document that includes an extensive bibliography and a detailed index.

During the summer of 1986, the National Security Archive was asked by several congressional offices to assist in gathering and analyzing information regarding the Iran-Contra affair. The Chronology (1987) is a documented day by day account of the secret military assistance to Iran and the Contras. The chronology has been constructed from a wide variety of sources, including the Report of the President's Special Review Board, the

Report on the Preliminary Inquiry of the Senate Select Committee on Intelligence, and congressional documents and reports. The material, including documents, is presented in rough chronological order, and entries are cross-referenced. Chronology is a resource for the public and a research tool for new investigations.

Revelations regarding the United States involvement in the Iran-Contra affair fueled criticism of the Reagan government. One group of essays reflecting this criticism is The Culture of Terrorism (1988) by Noam Chomsky. In this collection, Chomsky criticizes U.S. foreign policy, asserting that it is obvious from documentary and historical records that "the United States' international and security policy, rooted in the structure of power in the domestic society, has as its primary goal the preservation of...the fifth freedom." Chomsky defines the "fifth freedom" as the right "to rob, to exploit, and to dominate, to undertake any course of action, to ensure that existing privilege is protected and advanced." Chomsky completely disagrees with the U.S. government's clandestine operations in other countries, operations intended to influence the political history of countries in favor of U.S. economic and political interests. He uses Central America and the Iran-Contra Affair to illustrate this point. Significantly, he uses the word "terrorism" in a general sense to refer to any intervention, even by a government, in the affairs of another nation.

Three documentary books published to include the testimony of witnesses in the proceedings surrounding the Iran-Contra affair can be used as references for the public and Congress. Taking the Stand (1987) is the testimony of Lieutenant Oliver L. North before the congressional committee investigating the Iran-Contra episode. It is published by Pocket Books with an introduction by Daniel Schorr of CBS News. In his testimony, North reports the sequence 
of events as he witnessed them and answers detailed questions. The House Select Committee to Investigate Covert Arms Transactions with Iran and the Senate Select Committee on Secret Military Assistance to Iran conducted a series of hearings investigating the Iran-Contra Affair which have been published as Testimony of Richard V. Secord (1987) and Testimony of Robert C. McFarlane, Craston J. Sigur, Jr, and Robert W. Owen (1987). Both testimonies include appendixes containing very important documents, official letters, and handwritten accounts.

Five additional titles are: Report on the Congressional Committees Investigating the Iran-Contra Affair (1987); The Secret Government (1988), by Bill D. Moyers; Perilous Statecraft (1988), by Michael Arthur Ledeen; Men of Zeal (1988), by William S. Cohen; and Index to the Iran-Contra Hearings Summary Report (1988), by James Sanchez.

\section{PERIODICALS, RESOURCES, AND INDEXES}

The following are four of the many periodicals covering the Middle East: Middle East Journal (1947-); International Journal of Middle East Studies (1970-); The Middle Eastern Studies (1964-); and Middle East Economic Digest (1957-). These journals provide extensive articles of historical and political interest.

The Economist (1843-), a worldwide journal focusing on world news, has published many articles about the Iran-Iraq conflict and American foreign relations. Foreign Affairs (1922-), Foreign Policy (1979-), and Orbis: A Journal of World Affairs (1957-) specialize in politics and foreign affairs. The articles in these three journals are written by experts and scholars from various countries and reflect different points of view.

Time (1923-), U.S.A. Today (1915-), Newsweek (1933-) and U.S. News and World Report (1933-) very little in their coverage of Middle Eastern issues. They are popular, general, mass circulation news magazines that are widely read.

Readers will also find relevant literature scattered throughout periodicals of diverse disciplines, including: Perspective (1971-); Maclean's (1905-); Beijing Review (1958-); Daily World (1922-); UN Monthly Chronicle (1964-); Weekly Commentary and Pakistan News Digest; Strategic Reviews; American-Arab Affairs (1982-); Congressional Quarterly Weekly Report (1945-); Current History: A World Affairs Monthly; American Quarterly (1987-); Journal of South Asian and Middle East Studies (1977-); and Third World Quarterly (1979-).

\section{ONLINE SEARCHES}

The most valuable online searches on this topic are in LC MARC, REMARC, CIS, GPO Monthly Catalog, and PAIS International. All of these files are available through the DIALOG database.

\section{BIBLIOGRAPHIC SOURCES}

The literature of the Iran-Iraq war, the Islamic Revolution of Iran, and the U.S. Embassy hostage crisis has grown since 1978 and has continued to receive wide coverage in journals or newspapers. Fortunately, there are seven bibliographies that cover various aspects of the topic, and that deserve to be mentioned. The most comprehensive bibliography on the Iran-Iraq War is J. 
Anthony Gardner's The Iraq-Iran War: A Bibliography (1988). In his bibliography, Gardner includes books and journal articles in Western European languages and in Persian and Arabic that deal with the Iran-Iraq dispute through 1986. His work also includes published documents on the war and articles, generally under five pages in length, published in The New Republic, Nation, and other magazines known for their commentaries. The author has categorized the entries as follows: reference sources; published documents; general studies of the Iran-Iraq conflict that deal with both the pre-war and wartime periods; publications about the pre-1980 Iran-Iraq conflict; the war from 1980 to mid-1987; the war's impact on the Persian Gulf; and literature and visual images of the war. Gardner gives full bibliographic descriptions as well as annotations.

Another comprehensive bibliography is Ahmad Mahrad's Der Iran-Irak Konflikt (1985), which consists of related articles from the German, French, British, and American press, dating from 1970 to 1984. This bibliography includes a section on Iranian politics and a short history of the conflict between Iran and Iraq.

Two selective bibliographies have been published to reflect their library's holdings on this subject. The first is Iraq-Iran Conflict: Selected References (1986), compiled by Tomma N. Pastourett; the second is Iran and the United States, 1979-1981: Three Years of Confrontation: A Selected List of References (1982), compiled by Ibrahim V. Pourhadi. Pastourett lists books, documents, and periodical articles that are available at the Air University library. Pourhadi's selections are based on the Library of Congress holdings. His bibliography covers the roots of the Iranian revolution, the evolving confrontation with the United States, and developments in the hostage crisis and its consequences. Both bibliographies provide the call number used in their libraries and full bibliographic descriptions. They are helpful and easy to use.

Keith McLachlan's and Richard N. Schofield's A Bibliography of the Iran-Iraq Borderland (1987) provides a review of the literature covering the boundary dispute between Iran and Iraq, including matters affecting the entire frontier zone. The first three chapters are concerned with geography, geology, and geomorphology and their expression in the map form. Chapter four lists the main publications, currently available from libraries, on contemporary history and international relations that deal with events associated with the Iran-Iraq border. The authors are knowledgeable leaders in their fields, and the volume is intended for a specialized, scholarly audience.

The World Bibliographical Series (1988) provides a selective annotated bibliography on Iran by Riza Navabpour. It concentrates on works that can normally be found in the Middle East sections of university or large public libraries. This bibliography also refers to books that are still in press.

However, it does not include articles from newspapers and popular journals. Navabpour focuses on topics related to Khomeini, the Islamic Revolution, and the Persian Gulf war. Accompanying the bibliographic information are critical annotations to guide the reader. This resource is easy to use and useful for general readers as well as scholars.

Middle East in Conflict: Historical Bibliography (1985) offers convenient access to the major developments in Middle Eastern studies, covering journal literature on twentieth-century events in this important region. This bibliography represents major scholarship in history and in the related social sciences and humanities from over two thousand journals published in ninety countries in more than forty languages. 


\section{WORKS CITED}

Abdulghani, Jasim M. Iraq and Iran: the Years of Crisis. Baltimore, MD: Johns Hopkins University Press, 1984. \$32.50. 288p. ISBN 0-8018-2519-9. LC 84-47945.

Ajrab, Husayn Sulayman. Judhur Harb al-Khalij. Amman, al-Urdun: Dar al-Fikr, 1986. 2JD v. LC 87-963062.

American-Arab Affairs. 1982-. Q. 1730 M St. N.W., Suite 411, Washington, DC 20036.

American Quarterly. 1987-. Q. American Quarterly, 309 College Hall, University of Pennsylvania, PA 19104-6303.

Awwad, Nasif. Kalam Hadi fi Jaww Multahib. Baghdad: al-Dar al-Wataniyah (Distributor), 1980. $£$ £0.50. 1OOp. LC 83-961952.

Aziz, Tareq. The Iraq-Iran Conflict: Questions and Discussion. London: Third World Center for Research and Publishing; Baghdad: Translation and Foreign Languages Pub. House, 1981. £3.50. 89p. ISBN 0-8619-9010-2. LC 82-211684.

Bakka', Muhammad 'Abd al-Muttalib. Khumayni al-Tajribah al Mayyitah. Baghdad: al Dar al-Wataniyah lil-Nashr Wa-al-Tawzi', 1984. 2-5ID-91P. LC 85-963562.

Beijing Review. 1958-. W. P.O. Box 399, Beijing, China.

Chomsky, Noam. The Culture of Terrorism. Boston: South End Press, 1988. \$25; \$10 pbk. 270p. ISBN 0-896-083357; 0-89608-334-92. LC 87-28788.

Christopher, Warren. American Hostages in Iran: The Conduct of a Crisis. New Haven, CT: Yale University Press, 1985. \$13.95. 448p. ISBN 0-300-032331-5. LC 84-19592.

The Chronology. New York: Warner Books, 1987. \$5.95. 678p. ISBN 0-4463-4901-1. LC 87-152581.

Cohen, William S. Men of Zeal. New York: Viking, 1988. \$19.95. 350p. ISBN 0-670-82252-3. LC 88-40108.

Congressional Quarterly Weekly Report. 1945-. W. Congressional Quarterly Inc., 1414 22nd St. N.W., Washington, DC 20037.

Cordesman, Anthony H. The Iran-Iraq War and Western Security 1984-87: Strategic Implications and Policy Options. London: Janes Info. Group, 1987. \$28. 185p. ISBN 0-7106-0496-3. Current History: A World AffairMonthly. 1914-. 10/yr. 4225 Main St., Philadelphia, PA 19217.

Dabit, Shakir Sabir. Tarikh al-Munaza'at Wa-al-Hurub Bayna al-Iraq wa-Iran. Baghdad: al-Dar al-Wataniyah (Distributor), 1984. £E3.60. 451 p. LC 85-963520.

Daily World. 1922-. S-W. P.O. Box 544, New York, NY 10011. The Economist. 1843- W. 25 Saint 
James St., London, England SW1A 1HG.

Fatlawi, Suhayl Husayn. al Munaza'at al-Dawliyah. Baghdad: Dar al-Qadisiyah, 1986. 7ID. 552p. LC 86-234557.

Foreign Affairs. 1922-. 5/yr. 58 E. 68th St., New York, NY 10012. Foreign Policy. 1970-. Q.11 Dupont Circle, Washington, DC 20036.

Fredericks, Michael. The Octopus Eagle. Tallahassee, FL: Loiry Publishing House, 1987. 151p. ISBN 0-9337-0399-6. LC 87-17231.

Gardner, J. Anthony. The Iraq-Iran War: A Bibliography. London: Mansell Publishing Limited; Boston: Hall, G. K., \& Company, 1988. \$24. 124p. ISBN 0-7201-1879-4. LC gb88-14962.

Ghazzali, 'Abd al-Mun'im. Qadisiyat Saddam. Baghdad: al-Dar al-Wataniyah (Distributor), 1984. 125p. LC 85-963534.

Hammadi, Sa'dun. Mulahazat Hawla Qadiyat al-Harb ma'a Iran. Baghdad: al-Dar al-Wataniyah (Distributor), 1982. 0.6ID 174p. LC 84-963516.

Harb al-'Iraqiyah al-Mafrudah 'ala Jumhuriyat Iran al-Islamiyah. Tehran: Markz al Iiam al-Harbi' 1404, 1983 [or 1984]. 33p.

Haydar, Karrar. 'Udwan al-Nizam al-Iraqi Jarimah ma'a Sabq al-Israr. [s.1. : s.n.], 1984. \$3. 141p. LC 85-191012.

Heller, Mark. The Iran-Iraq War: Implications for the Third Parties. Tel Aviv: Jaffee Center for Strategic Studies, Tel Aviv University; Cambridge, MA: The Center for International Affairs, Harvard University, 1984. 49p. LC 84-162155.

al-Iman Yuqawimu al-I'tida'. Tihran: Markaz I'lam al-Dhikra al-Thalithah li-Intisar al-Thawrah al-Islamiyah, 1982. 94p. LC 84-930967.

International Journal Of Middle East Studies. 1970-. Q. Cambridge University Press, 32 E. 57th St., New York, NY 10022.

Ioannides, Christos P. America's Iran: Injury and Catharsis. London: University Press of America, 1984. \$24.75; \$13.50 pbk. 328p. ISBN 0-8191-4189-5; 0-819-14190-9. LC 84-13170.

The Iron-Contra Arms Scandal. New York: Facts on File Publications, 1988. 216p. ISBN 0-8160-1859-6. LC 87-15606.

The Iran-Contra Puzzle. Washington, DC: Congressional Quarterly, 1987. \$19.95. 506p. ISBN 0-87187-442-3. LC 87-24571.

The Iran-Iraq War: An Historical, Economic, and Political Analysis. Ed. by M. S. El-Azhary. New 
York: St. Martin's Press, 1984. \$25. 160p. ISBN 0-312-43583-5. LC 83-16148.

The Iran-Iraq War: Issues of Conflict and Prospects for Settlement: Proceedings of a Seminar Organized by the Center of International Studies. Ed. by Ali E. Hillal Dessouki. Princeton, NJ: Center of International Studies, Woodrow Wilson School of Public and International Affairs, Princeton University, 1981. \$7.50 pbk. 119p. LC 82-115421.

The Iran-Iraq War: Old Conflict, New Weapons. Ed. by Shirin Tahir-Kheli and Shaheen Ayubi. New York: Praeger, 1983. \$30.95. 224p. ISBN 0-275-91088-1. LC 82-15121.

Iraq-Iran Conflict: Selected References. Comp. by Tomma N. Pastourett. Alabama: Air Univ. Library, 1986. 36p. LC 86-602455.

Ismael, Tareq Y. Iraq and Iran: Roots of Conflict. Syracuse, NY: Syracuse University Press, 1982. \$24; \$12.95 pbk. 226p. ISBN 0-8156-2279-1; ISBN 0-8156-2280-5. LC 82-10562.

Izzi, Khalid Yahya. The Shatt-al-'Arab Dispute: A Legal Study. London: Third World Center for Research and Publishing, 1981. \$20. 243p. ISBN 0-266-55056-7. LC 83-210694.

Jordan, Hamilton. Crisis: The Last Year of the Carter Presidency. New York: Putnam, 1982. \$16.95. 431p. ISBN 0-3991-2738-0. LC 82-11299.

Journal of South Asian and Middle Eastern Studies. 1977-. Q. Published under the auspices of the Pakistan American Foundation, 138 Tolentine Hall, Villanova, PA 19085.

Juhud al-Salam al-Dawliyah li-Iqaf al-Harb al-Iraqi-yah al-Iraniyah. Baghdad: al-Dar al-Wataniyah (Distributor), 1983. 0.25ID 93p. LC 84-963523.

Kanovsky, Eliyahu. The Iran-Iraq War: Its Economic Implications. Tel Aviv: Shiloah Center for Middle Eastern and African Studies, Tel Aviv University, 1983. 23 leaves. LC 83-204840.

Khadduri, Majid. The Gulf War: The Origins and Implications of the Iraq-Iran Conflict. New York: Oxford University Press, 1988. \$24.95. 254p. ISBN 0-19-504529-7. LC 87-38328.

King, Ralph. The Iran-Iraq War: The Political Implications. London: International Institute for Strategic Studies, 1987. \$4. 76p. ISBN 0-860-79113-0. LC 87-163315.

Ledeen, Michael Arthur, and Lewis, William. Debacle: The American Failure in Iran. New York: Random House, 1981. \$14.95. 256p. ISBN 0-394-51657-7. LC 80-2714.

Ledeen, Michael Arthur. Perilous Statecraft. New York: Scribner, 1988. \$19.95. 320p. ISBN 0-684-18994-1. LC 88-19014.

Lytle, Mark Hamilton. The Origins of the Iranian-American Alliance, 1941-1954. New York: Holmes and Meier, 1987. \$49.50; \$17.50 pbk. 254p. ISBN 0-8419-1060-x; 0-8419-1061-8. LC 86-26931. 
Maclean's. 1905-. W. P.O. Box 1600, Station A, Toronto, Ontario M5W 2 B8.

Mahrad, Ahmad. Der Iran-Irak Konflikt. Frankfurt am Main; New York: P. Lang, 1985. 401p. ISBN 3-8204-8504-x. LC 85-230826.

Marshall, Jonathan; Scott, Peter Dale; and Hunter, Jane. The Iran-Contra Connection. Boston, MA: South End Press, 1987. \$30. 350p. ISBN 0-89608-292-x. LC 87-13059.

McLachlan, Keith, and Schofield, Richard N. A Bibliography of the Iran-Iraq Borderland. Cambridgeshire, England: Middle East \& North African Studies Press, 1987. \$26. 383p. ISBN 0-906-55921-9. LC gb87-16509.

Meyer, Peter. Defiant Patriot: The Life and Exploits of Lt. Colonel Oliver L. North. New York: St. Martin's Press, 1987. \$4.50 pbk. 287p. ISBN 0-312-91091-6.

Middle East Economic Digest. 1957-. W. MEED House, 21 John St. London WC1N 2BP, England.

Middle East in Conflict: Historical Bibliography. Santa Barbara, CA: ABC-Clio Co., 1985. \$69. 302p. ISBN 0-87436-381-0. LC 83-27530.

Middle East Journal. 1947- Q. 1761 N St. N.W., Washington, DC 20036.

Middle Eastern Studies. 1964-. 3/yr. Frank Cass \& Co. Ltd, Gainsborough House, N. Gainsborough Rd., London Ell IRS, England.

Moody, Sidney. 444 Days: The American Hostage Story. New York: Rutledge Press, 1981. \$4.95. 192p. ISBN 0-8317-4570-3; 0-8317-4571-1.

Moyers, Bill D. The Secret Government. Lanham, MD: Seven Locks Press, 1988. \$14.95 131p. ISBN 0-9320-2061-5. LC 88-3131.

Mukhif, 'Ali 'Abd al-Husayn. Fi Qissat al-Harb. Baghdad: Tawzi Dar al Wataniyah (Distributor), 1984. 6ID. 219p. LC 85-963592.

Navabpour, Riza. Iran. World Bibliographic Series, no. 81. Santa Barbara, CA: Clio Press, 1988. \$39.50. 308p. ISBN 1-851-09036-3. LC gb87-35714.

Nazrah ila 'Amayn min al-Harb. Tehran: al-Maktab al-Siyasi li-Haras al-Thawrah al-Islamiyah, 198-. 181p. LC 85-174516.

Newsweek. 1933-. W. 444 Madison Ave., New York, NY 10022.

al-Niza' al-Iraqi al-Irani fi al-Qanun al-Dawli. Baghdad: Jumhuriyah al-'Iraqiyah, Wizarat al-Kharijiyah, al-Lajnah al-Istishariyah, 1981. 197p. LC 84-176318. 
Orbis: A Journal of World Affairs. 1959-. Q. 3508 Market St., Suite 350, Philadelphia, PA 19101.

Perspective. 1971-. 10/yr. 4000 Albermarle St. N.W., Suite 504, Washington, DC 20016.

Peterzell, Jay. Reagan's Secret War. Washington, DC: Center for National Security Studies, 1984. \$3.50. 1OOp. ISBN 0-86566-033-6. LC 85-173051.

Pourhadi, Ibrahim V. Iran and the United States, 1979-1981: Three Years of Confrontation: A Selected List of References. Washington, DC: Near East Section, African and Middle Eastern Division, Library of Congress, 1982. 37p. LC 82-222064.

Preliminary Inquiry into the Sale of Arms to Iran and Possible Diversion of Funds to the Nicaraguan Resistance. Washington, DC: U.S. G.P.O., 1987.

Rubin, Barry M. Paved with Good Intentions: The American Experience and Iran. New York: Oxford University Press, 1980. \$17.50 426p. ISBN 0-19-502805-8. LC 81-004634.

Ryan, Paul B. The Iranian Rescue Mission: Why It Failed. Annapolis, MD: Naval Institute Press, 1985. \$13.95. 185p. ISBN 0-8702-1321-0. LC 85-7310.

Sada al-Harb: Muqtatafat Mimm Katabathu al-Siha-fah al-'Alamiyah 'an al-Harb al-da' Irah Bayna al-'Iraq wa-Iran. Tehran, s.n., 1983. LC 85-193633.

Sa'id, Hamid. al-Dars al-Iraqi fi Harb Radd al-'Udwan. Baghdad: al Dar al Wataniyah (Distributor), 1982. 0.6ID. 105p. LC 84-159424.

Qira'ah fi Awraq 'Arabiyah 'ala Daw'al-Harb al-Iraqiyah al-Iraniyah. Baghdad: al-Dar al-Wataniyah (Distributor), 1983. 0.6ID. 135p. LC 84-963591.

Salinger, Pierre. America Held Hostage: The Secret Negotiations. New York: Doubleday, 1981. \$16.95. 349p. ISBN 0-385-17750-x. LC 81-43127.

Salman, Sabah. Adwa' 'ala al-Harb al-Iraqiyah al-Iraniyah. Baghdad: Wizarat al-Thagafah wa-al-I'Lam, Da'irat al-I'Lam, al Dakhili al-'Ammah, 1981. 0.150ID. 194p. LC 81-175136.

Samarah, 'Adil. al-Harb al-Iraqiyah al-Iraniyah. S.L.: Dar al-Amil, 1980.

Samii, Kuross A. Involvement by Invitation: American Strategies of Containment in Iran. State College: Pennsylvania State University Press, 1987. \$24.95. 208p. ISBN 0-271-00490-8. LC 86-43035.

Sanchez, James. Index to Iran Contra Hearings Summary Report. Jefferson, NC: McFarland, 1987. \$19.95. 82p. ISBN 0-8995-0356-x. LC 88-42555.

Index to the Tower Commission Report. Jefferson, NC: McFarland, 1987. \$8.95. 57p. ISBN 0-899-50299-7. LC 87-3116. 
Sick, Gary. All Fall Down: America's Tragic Encounter with Iran. New York: Penguin Books, 1986. \$8.95. 432p. ISBN 0-1400-8837-7. LC 86-198294.

al-Sira' al-'Arabi al-Farisi. Baris: Manshurat al-'Alam al-Arabi, 1981. 309p. ISBN

2-8658-4001-8. LC 82-121074.

Soviet-American Relations with Pakistan, Iran, and Afghanistan. Ed. by Hafeez Malik. New York: St. Martin's Press, 1987. \$25. 431p. ISBN 0-312-00240-8. LC 86-021898.

Sreedhar. Iraq-Iran War. New Delhi: ABC Publishing House, 1985. RS 96.00. 234p. LC 85-904381.

Stempel, John D. Inside the Iranian Revolution. Bloomington: Indiana University Press, 1981. \$17.50. 336p. ISBN 0-253-14200-8. LC 81-47564.

The Story of Lieutenant Colonel Oliver North. Washinton, DC: U.S. News \& World Report, 1987. \$4.95. 128p. LC 87-210552.

Strategic Review. 1973-. Q. United States Strategic Institute, P.O. Box 8100, Boston, MA 02114. Sullivan, William H. Mission to Iran. New York: Norton, 1981. \$14.95. 296p. ISBN 0-393-01516-5. LC 81-14052.

Tawalibah, Hasan Muhammad. Munaqashah fi al-Niza' al-Iraqi al-Irani. Bayrut: al-Watan al-al-Arabi, 1984. £E 4. 180p. LC 86-108265.

Third World Quarterly. 1979-. Q. Third World Foundation, New Zealand House, 80 Haymarket, London SW 14 4TS, England.

Time. 1923-. W. 3435 Wilshire Blvd., Los Angeles, CA 90010.

U.N. Monthly Chronicle. 1964-. M. United Nations Publishing, Rm. A-3315, New York, NY 10017.

U.S. News and World Report. 1933-. W. 2300 N. St. N.W., Washington, DC 20037.

U.S.A. Today. 1915-. M. 1860 Broadway, New York, NY 10023.

United States. President's Special Review Board. The Tower Commision Report. New York: Bantam Books, 1987. \$5.50 pbk. ISBM 0-317-57616-X.

United States. Congress. House. Select Committee to Investigate Covert Arms Transactions with Iran. Report of the Congressional Committees Investigating the Iran-Contra Affair. New York: Time Books, 1987.

Report of the Congressional Committees Investigating the Iran-Contra Affair. For sale by the Supt. of Docs., U.S. G.P.O., 1987. 
Testimony of Richard V. Secord. For sale by the Supt. of Docs., U.S. G.P.O., 1987.

Testimony of Robert C. McFarlane, Gaston J. Sigur, Jr. and Robert W. Owen. For Sale by the Supt. of Docs., U.S. G.P.O., 1987.

The United States and Iran: A Documentary History. Ed. by Yonah Alexander and Allan Nanes. Frederick, MD: University Publications of America, 1980. $\$ 8$ pbk. 524p. ISBN 0-89093-378-2. LC 80-53318.

Weekly Commentary and Pakistan News Digest. 1972-. Islamabad: Ministry of Foreign Affairs, Government of Pakistan, v. LC 72-931087.

Wells, Tim. 444 Days: The Hostages Remember. San Diego, CA: Harcourt Brace Jovanovich, 1985. \$19.95. 469p. ISBN0-15-132803-X. LC 85-010038.

Wijhat Nazar al-Sihafah al-Gharbiyah fi al-Niza' al-Iraqi al-Irani. Al Basrah: Markaz Dirasat al-Khalij al-'Arabi bi-Jami'at al-Basrah, Shu'bat al-Dirasat al-Siyasiyah wa-al Istiratijiyah, 1983. 0.6ID. 139p. LC 84-110056.

Wuhayyib, Hani. Malahim Khalidah Fi Qadisiyat Saddam. Baghdad: al-Dar al-Wataniyah (Distributor), 1984. 0.6ID. 196p. LC 85-963564.

Yasin, Sabah. al-Ma'rakah Wa-Muqaddimat al-Nasr. Baghdad: al-Dar al-Wataniyah (Distributor), 1982. 0.2ID. 90p. LC 84-963526. 